\title{
A call for freedom
}

It was one of those white summer nights for which St. Petersburg is famous. The small crowd that gathered in the early hours of July I3, I826 on the Holy Trinity Bridge across the Neva River and on the shore near the SS. Peter and Paul Fortress could clearly see the gruesome ritual taking place on the ramparts of the fortress. First, to the accompaniment of drumbeats, dozens of young and middle-aged men were led out of the fortress, most of them dressed in dirty and worn-out officers' uniforms. They were then divided into smaller groups and brought in front of the military detachments, summoned to the scene, in which they had once served and that some of them had led into battle. They listened calmly as the verdict of the court was read out, sentencing them to years of hard labor and exile. After the sentence was read, the convicts were brought to their knees and their sabers broken above their heads, signaling the revocation of their noble status, officer ranks, awards, and distinctions. Their epaulettes and military uniforms were burned in front of the fortress.

Once the ritual of "civic execution" was over and the convicts taken back inside the fortress, those gathered on the banks of the Neva could see guards escorting five more men in heavy chains out of the fortress gates. They led them to the gallows that had been hastily constructed on the riverbank. There was a pause as the executioners looked for benches on which to place the five men awaiting execution. They finally found some in the abandoned naval school nearby. What followed sent a chill through everyone who witnessed the scene, including the executioners themselves. As drums beat and the hangmen removed the benches and the floor of the scaffold from under the condemned men's feet, only two of them hung on their ropes, while the three in the middle fell into the ditch beneath the gallows. The ropes used to hang them proved too weak to carry the weight of their bodies and the chains around their 
ankles. There was a sigh of relief and astonishment among those present at the execution. Would the men be saved?

"God does not want them dead," said one of the guards, but the military governor of St. Petersburg, General Pavel Golenishchev-Kutuzov, ordered the survivors to be brought back to the scaffold and hanged again. The scenario of the execution had been written by Emperor Nicholas I himself, and the battle-scarred general, who had distinguished himself in the Battle of the Nations at Leipzig in 1813 and was then dispatched to St. Petersburg from Paris with the news of Napoleon's defeat, was determined to carry out the emperor's orders to the end. Nicholas had wanted the execution to be over by four o'clock in the morning: it was now close to five, with the sun up and the darkness all but gone, yet three convicts accused of high treason were still alive. Golenishchev-Kutuzov ordered his hangmen to hurry. The stunned and bloodied survivors, one of them barely able to walk, were led out again onto the hurriedly rebuilt scaffold. "It's an accursed land where they don't know how to plot, judge, or hang," one of them is alleged to have said. Another shouted at Golenishchev-Kutuzov: "Base lackey of a tyrant! Give the executioner your ornamental pins so that we don't die a third time!" The general was unmoved. By six o'clock the execution was finally over. The bodies of the five prisoners who believed that they had given their lives in the fight for freedom were removed from the scene. Next day their remains were transported to Goldai Island near St. Petersburg and buried in an unmarked grave.

The five men hanged that summer morning of 1826 on the banks of the Neva were the leaders of the Decembrist conspiracy, organized by veterans of the Napoleonic Wars who sought to change the political order of the Russian Empire. On December I4, I825, seven months before the gruesome execution on the ramparts of the SS. Peter and Paul Fortress, a score of young, idealistic Russian officers had led their troops to the Senate Square in St. Petersburg with the hope of toppling the autocracy, abolishing serfdom, and convening a constitutional assembly. Their troops were surrounded by detachments loyal to the tsar and dispersed by artillery fire. A subsequent rising of the Chernihiv regiment in Ukraine was also suppressed. After a six-month investigation, the leaders of the two uprisings were hanged, participants and members of Decembrist circles exiled to Siberia or sent to wage war in the Caucasus. The revolt was crushed, plans for the radical restructuring of the empire (some of which included such drastic measures as the introduction of military dictatorship) dashed, and the autocracy emerged victorious. But the example of the five martyrs and 
the dream of freedom kindled by the leaders of the revolt would live on, inspiring future generations of rebels. ${ }^{\mathrm{I}}$

The man who called General Golenishchev-Kutuzov a "base lackey of a tyrant" was a thirty-year-old retired officer and manager of the RussianAmerican Company in St. Petersburg, Kondratii Ryleev. He was the heart and soul of the Decembrist circle in St. Petersburg. It was in his apartment that the revolt was planned in the days leading up to December I4, 1825. A friend of Alexander Pushkin and an acclaimed poet in his own right, Ryleev inspired his friends and co-conspirators not only with his fiery poetry, in which he called on his readers to fight for freedom even at the cost of their lives, but also by his stoicism at the time of his execution. When a priest tried to console him, Ryleev took the priest's hand, put it on his chest and said, referring to his own heart: "Feel, Father, it's not beating any faster than before."

Ryleev's friends believed that he had foreseen his own death when, a few months before the uprising, he published a short excerpt from a poetic novel on which he was working at the time. The poetic novel, titled Nalyvaiko, had as its main protagonist the leader of a late-sixteenthcentury Cossack uprising in Ukraine. In the excerpt, titled "Nalyvaiko's Confession," Ryleev put the following words into the mouth of the Cossack leader as he faced execution:
I know full well the direful fate
Which must upon the patriot wait
Who first dares rise against the foe
And at the tyrant aim the blow.
This is my destined fate - but say
When, when has freedom won her way
Without the blood of martyrs shed,
When none for liberty had bled?
My coming doom I feel and know,
And bless the stroke which lays me low,
And, father, now with joy I meet
My death, to me such end is sweet. ${ }^{3}$

\footnotetext{
I "Kazn' dekabristov. Rasskazy sovremennikov," in Russkii arkhiv 2 (I88I): 34I-46; Nestor Kotliarevskii, Ryleev (St. Petersburg, I908), pp. I86-9I; "Dekabristy. Istoriia vosstaniia I4 dekabria I825 goda na Senatskoi ploshchadi v Peterburge," www.patiks.ru/txt/3dekab77.shtml. On the Decembrist Revolt, see Anatole G. Mazour, The First Russian Revolution, I825: The Decembrist Movement (Stanford, Calif., 1966).

2 "Dekabristy. Istoriia vosstaniia I4 dekabria I825 goda." On Ryleev, see Patrick O. Meara, K. F. Ryleev: A Political Biography of the Decembrist Poet (Princeton, N.J., 1984).

${ }^{3}$ K. F. Relaieff, Voinarofskyi and Other Poems, trans. T. Hart-Davies (Calcutta, I879), p. IO2.
} 
When Ryleev first read this verse to his friend Mikhail Bestuzhev, who, along with his brother Nikolai, led the first rebel detachments to the Senate Square on December I4, I825, Mikhail was shocked. According to the memoirs of Nikolai Bestuzhev, he told Ryleev: "Do you know what prediction you have written for yourself and for both of us?" Ryleev was fully aware of the significance of his words. "Do you really think that I hesitated even for a minute about my purpose?" he asked his friend. "Believe me that every day convinces me of the inevitability of my actions, of the coming death with which we must redeem our first effort on behalf of free Russia and, along with this, of the need for an example in order to awaken the sleeping Russians." 4

Ryleev's verses inspired generations of revolutionaries and freethinkers in the Russian Empire. Among them were Vera Zasulich, a revolutionary assassin and one of the first Russian Marxists, and Mykhailo Drahomanov, an exile and the most influential Ukrainian political thinker of the nineteenth century. Drahomanov later recalled that in the mid I850s, "The Confession of Nalyvaiko was copied in our secret notebooks along with the works of Shevchenko and was read with equal zeal." Ryleev himself drew inspiration from historical works, and in the last year before the uprising he was particularly fascinated by the history of the Ukrainian Cossacks. ${ }^{5}$

Kondratii Ryleev first became acquainted with Ukraine through his father, who served in Kyiv and even bought a house there that he bequeathed to his son. The young Ryleev's first encounter with the Cossack way of life took place after his return from the Napoleonic Wars. In February I8I4 he joined the Russian army after graduating from a military college at the age of eighteen. With his artillery brigade, the young Ryleev marched through Poland, Germany, Switzerland, and France. In Dresden he was received at the court of the Russian ruler of Saxony, Nikolai Repnin, the future governor general of Little Russia, who was married to the granddaughter of the last hetman of Ukraine, Kyrylo Rozumovsky. Ryleev also spent some time in Paris. "I was infected with freethinking during the campaigns in France in I8I4 and I8I5," he testified after his arrest. Following the European campaigns, his detachment was brought back to the Russian Empire and stationed first in Lithuania and then in the vicinity of Ostrogozhsk (Ostrohozk), a town

\footnotetext{
4 Vospominaniia Bestuzhevykh (Moscow and Leningrad, I95I), p. 7.

5 Mykhailo Drahomanov, Lysty na Naddniprians'ku Ukrä̈nu, in Mykhailo Drahomanov and Borys Hrinchenko, Dialohy pro ukraïn''ku natsional'nu spravu (Kyiv, I994), p. I6o.
} 
on the southern border of today's Russian Federation. Founded by Ukrainian Cossacks in the mid seventeenth century, Ostrogozhsk served as the headquarters of a Cossack territorial and military regiment until the I76os. At the turn of the nineteenth century, for a short time, it was part of the imperial gubernia of Sloboda Ukraine. Its inhabitants preserved their Ukrainian customs and traditions well into the twentieth century. ${ }^{6}$

Ryleev spent close to three years in the vicinity of Ostrogozhsk, befriending local officers and becoming attached to the local culture. There he also found the love of his life, the daughter of a local nobleman. Natalia Teviashova came from a family of Cossack officers, with one of her ancestors serving as colonel of the Ostrogozhsk regiment in the early eighteenth century. After resigning from the military at the end of I8I8 and eventually moving to St. Petersburg with his wife, Ryleev would come back to the region, to which he invariably referred as "Ukraine," in order to spend the summers in the company of his old friends. In December I825, Ryleev wrote to Mykola Markevych, a descendant of a prominent Cossack family and a future historian of Ukraine: "I am a Russian, but I have spent three years in Ukraine: a short time for me, but sufficient to fall in love with that land and its fine inhabitants. Moreover, Ukraine has presented me with an uncommon, incomparable wife. My good Ukrainian lady has now been making me happy for six years, and so my attachment is complemented with the gratitude of my soul." 7

Kondratii Ryleev did not forget his Ukrainian friends and acquaintances when he moved to St. Petersburg. In November 1820, having returned to the imperial capital after spending the summer in the Ostrogozhsk region, Ryleev published a letter in Otechestvennye zapiski (Fatherland Notes), a leading journal of the time, in which he praised his Ostrogozhsk friend Mikhail Bedraga, a retired officer of the Okhtyrka (Akhtyrka) hussar regiment. Established initially as a territorial and military unit of Ukrainian Cossacks in 1651, the Okhtyrka regiment was reformed into a hussar regiment in 1765 after the abolition of Cossack autonomy in the region. In I8I4 the regiment entered Paris, where the Cossacks-turned-hussars used brown fabric that they requisitioned at a Capuchin convent to make new

${ }^{6}$ Ibid., pp. 8-Iо; Kotliarevskii, Ryleev, pp. 2I-24; B. T. Udodov, K. F. Ryleev v Voronezhskom krae (Voronezh, 197I), pp. 5-I4.

7 Kotliarevskii, Ryleev, pp. 24-29; K. F. Ryleev to Mykola Markevych, in Literaturnoe nasledstvo, ed. A. M. Egolin et al. (Moscow, I954), vol. LIX, p. I53. 
uniforms. These impressed Emperor Alexander I, who ordered that regimental uniforms be brown thereafter. ${ }^{8}$

Ryleev's letter was a follow-up to the note published in Otechestvennye zapiski by the legendary Russian poet Denis Davydov, an organizer of partisan warfare during the Napoleonic campaigns and the former commander of the Okhtyrka regiment. Davydov praised his former subordinate. Mikhail Bedraga came from the family of Major General Grigorii Bedraga. He was a dedicated and brave officer who served in the Okhtyrka regiment together with his two brothers from a very early age and fully demonstrated his outstanding qualities as a military commander during the Napoleonic Wars. Bedraga did not make it to Paris: having suffered a head wound in the famous Battle of Borodino (I8I2), he lived in isolation and obscurity on his family estate near Ostrogozhsk.

In a poem dedicated to Bedraga and written in the summer of I82I, Ryleev described conversations he had had with one of his Ostrogozhsk acquaintances, probably his father-in-law, Major Mikhail Teviashov. The subjects they discussed included the rebellion of the Greeks against Ottoman rule that was then under way in Morea, as well as the history of the Zaporozhian Sich, the Cossack stronghold below the Dnieper rapids, which served as a symbol of the struggle for Cossack freedom. It might be assumed that Ryleev had similar conversations with Bedraga. In a poem dedicated to his friend, Ryleev wrote:

We talked of deeds of yore,
Of freedom-loving Sich,
Of peace and then of war,
Till, surfeited with speech,
To supper we would go.
At table, as we dined,
The major on occasion
To argument inclined,
Made bold by his libation.

For Ryleev, the Ostrogozhsk Cossacks became champions of freedom and liberty inherited from their heroic past. The Cossack tradition never died out there, even among the peasants. "I do not consider it superfluous to say that peasant serfs were nowhere to be seen in the lands of Ostrogozhsk

${ }^{8}$ K. F. Ryleev, "Eshche o khrabrom M. G. Bedrage," in Sochineniia i perepiska Kondratiia Fedorovicha Ryleeva, 2nd edn. by his daughter, ed. P. A. Efremov (St. Petersburg, 1784), pp. 194-97; Aleksandr Mikhailenko, I zhili druzhnoiu semeiu soldat, kornet i general (Moscow, 200I), ch. I-2.

9 K. F. Ryleev, "Pustynia (K M. G. Bedrage)," in Sochineniia i perepiska, pp. I7I-76. 
until the end of the last century. The regimental lands that came into the possession of various officials of the Ostrogozhsk regiment were tilled by freemen or Cossacks," he wrote in one of his appeals to St. Petersburg authorities, advocating the return of economic freedom to the area, which suffered under difficult conditions. The tradition of Cossack freedom was indeed alive and well in the region. One of the local peasants who was ransomed out of serfdom with Ryleev's help later recalled that his grandfather, "taciturn, humble, and sensible when sober, once he had had something to drink ... was in the habit of holding forth on public affairs, recalling Cossackdom and the Hetman state; he was a harsh critic of the corruption of rural administration." ${ }^{\circ}$

Ryleev regarded Ostrogozhsk as a place where the tradition of freedom was passed on from fathers to sons and grandsons. It was a place where, as he wrote in his poem of 1823 ,

Captive to the sound of glory,

An aged man, from battles hoary,

Inspired a seething generation

To victory and liberation. ${ }^{\text {II }}$

The poem described a meeting at Ostrogozhsk in 1696 between Tsar Peter I and the Cossack hetman Ivan Mazepa - allies at the time, but later adversaries. In 1708 Mazepa led the Ukrainian Cossacks in revolt against Peter I and joined forces with the advancing army of King Charles XII of Sweden. The emperor declared Mazepa a traitor and had him anathematized by the Russian Orthodox Church. The anathema was repeated annually in churches throughout the empire. ${ }^{\mathrm{I2}}$

Ryleev did not shrink from engaging not only politically sensitive but plainly dangerous subjects. In the spring of I823 Ryleev began work on a poetic novel, titled Voinarovsky, about Mazepa's revolt and its consequences. The protagonist was a young and idealistic nephew of Mazepa, Andrii Voinarovsky, who joined his uncle's rebellion against the tsar and followed him into emigration. He served as Charles XII's special representative in Istanbul. On his way from the Ottoman Empire to Sweden in

Io K. F. Ryleev, "Ob Ostrogozhske," in Sochineniia i perepiska, pp. 193-94; Udodov, K. F. Ryleev v Voronezhskom krae, pp. 22-26, 67.

${ }^{\text {II }}$ K. F. Ryleev, "Petr Velikii v Ostrogozhske," in Sochineniia i perepiska, pp. 58-6I.

${ }^{12}$ On Mazepa and his revolt, see Oleksander Ohloblyn, Het'man Ivan Mazepa i ioho doba (New York, Paris and Toronto, 1960); Orest Subtelny, ed., On the Eve of Poltava: The Letters of Mazepa to Adam Sieniawski, I704-I708 (New York, 1975); Subtelny, The Mazepists: Ukrainian Separatism in the Early Eighteenth Century (New York, 198I); Teodor Mackiw, English Reports on Mazepa, Hetman of Ukraine and Prince of the Holy Roman Empire, I687-I709 (New York, Munich, and Toronto, 1983). 
October 1716, he was kidnapped by Russian agents and imprisoned in the SS. Peter and Paul Fortress. He was then sent to Yakutsk in Eastern Siberia, where he died after spending sixteen years in exile. Voinarovsky turned out to be prophetic - if not for Ryleev himself, then for those of his colleagues who were sent to Siberia after the suppression of the Decembrist Revolt. ${ }^{\mathrm{I}}$

The most controversial feature of the poetic novel was its portrayal of the old Cossack hetman. Despite an introduction to the poem that followed the tradition of Russian imperial historiography by casting Mazepa as a self-seeking traitor, the hetman appeared in some scenes of the work as a devoted patriot of his fatherland, ready to die for its freedom in the struggle against tyranny. The introduction was written by Aleksandr Kornilovich and the poem itself by Ryleev. Such was the image that Ryleev presented in the episode where Voinarovsky recounts his first meeting with his uncle to discuss rebellion against the tsar. Ryleev's Mazepa tells his young nephew:
Under fate's hand, full well I know
The step is bold, what may betide
But future fortune can decide,
Success may not attend the blow,
Glory may gild my conquering name,
Or foul disgrace may blast my fame,
But I am firm, though o'er my land
Fate threatening dark disaster stand.
The hour is near, the strife at hand,
On our side freedom's banners fly
Ranged against ruthless tyranny. ${ }^{\text {I4 }}$

Excerpts from the poetic novel, followed by the complete work (with significant omissions ordered by the vigilant censor), appeared in print in I824 and I825, and the reading public received the novel with enthusiasm. Alexander Pushkin was among its admirers. But there were critical reactions as well. In a private letter written in April I825, Pavel Katenin, another freethinker who had been exiled from St. Petersburg long before the December 1825 uprising, wrote to an acquaintance: "These are all copies of various works of Byron's in verse according to the new style; what I find strangest of all is the thought of presenting the knave and scoundrel Mazepa as a new Cato of some sort."15

${ }^{13}$ Liubomyr Vynar, Andrii Voinarovs'kyi: istorychnyi narys (Munich and Cleveland, 1962).

${ }^{14}$ Relaieff, Voinarofskyi and Other Poems, pp. 6o-6I; A. Kornilovich, "Zhizneopisanie Mazepy," in Ryleev, Sochineniia i perepiska, pp. 9I-96.

is K. F. Ryleev, "Pis'ma k A. S. Pushkinu," in Sochineniia i perepiska, pp. 203-6; Kotliarevskii, Ryleev, pp. 54-55, II7-2I; Russkaia romanticheskaia poèma, ed. Viktor Afanas'ev (Moscow, 1985), p. II3. 
There was some truth in Katenin's treatment of Ryleev's new work as a reflection of Byron's literary style and sympathies. In the summer of I8I9, Byron published his narrative poem Mazeppa to universal acclaim, instantly launching the eighteenth-century Cossack hetman on his posthumous career as a Romantic hero. Still, Ryleev was quite original both in his selection of his main protagonist, Voinarovsky (who was not even mentioned by Byron), and in his interpretation of the character of Mazepa, who emerged in Ryleev's work as a vehicle for the poet's expression of his own views on freedom and tyranny. Byron was only partly responsible for Ryleev's lenient treatment of Mazepa, or for the glorification of Cossack hetmans in general. Ryleev's subsequent poetry left no doubt in that regard. ${ }^{16}$

In I82I-23 Ryleev published a selection of poems under the title Dumy. They were inspired by the Historical Songs published in I8I6 by Julian Ursyn Niemcewicz, a Polish poet and historian who was a strong supporter of the Polish Constitution of I79I and served as a secretary to Tadeusz Kościuszko, the leader of the Polish uprising of 1794 against Russian rule. Ryleev knew Polish from his childhood, and Polish patriots, including Adam Mickiewicz, were welcome in Decembrist circles. Still, Ryleev was adamant that the Polish author's historical songs were not his only or primary inspiration. In the introduction to his collection of Dumy issued in I825, he wrote: "The duma is an ancient inheritance from our southern brethren - our own native Russian invention. The Poles took it from us. To this day the Ukrainians sing dumy about their heroes Doroshenko, Nechai, Sahaidachny, Palii - and the composition of one of them is attributed to Mazepa himself." The word duma is indeed the Ukrainian term for lyrical and epic songs of folk origin. Ryleev was probably familiar with the first collection of Ukrainian folk songs published by Nikolai Tsertelev in St. Petersburg in I8I9 and knew the first work of modern Ukrainian literature, Ivan Kotliarevsky's Eneïda, a folk parody based on Virgil's Aeneid first published in St. Petersburg in $1798 .{ }^{17}$

There is reason to believe that sometime in 1824 Ryleev gained access to a new and fascinating source on the Cossack past. It was known to him and some of his friends as the Konysky History, and its authorship was attributed to the Orthodox archbishop of Mahilioŭ, Heorhii Konysky.

${ }^{16}$ On Mazepa as a Romantic hero, see H. F. Babinski, The Mazeppa Legend in European Romanticism (New York, 1974).

${ }^{17}$ K. F. Ryleev, "Dumy," in Sochineniia i perepiska, pp. I-2; Drahomanov, Lysty na Naddniprians'ku Ukraïnu, p. 156. 
The manuscript was not available to Ryleev in its entirety. The full text was hidden away in the Chernihiv area, far to the south of the imperial capital, in the libraries of the descendants of Cossack officers. But the excerpts of the mysterious manuscript that Ryleev was able to get his hands on ignited his romantic imagination. They opened up a world full of Cossack heroes. One of them, Severyn Nalyvaiko, was barely known not only in Western but even in Russian and Ukrainian historical writing until the I82os. Nalyvaiko and his endeavors were allotted a mere two sentences in the first scholarly history of Ukraine, a two-volume work by Dmitrii Bantysh-Kamensky published in I822. It was only the Konysky History that finally satisfied the interest of readers in the details of the Nalyvaiko affair. One might have assumed from the introduction to the work that those details came from the archives of Bohdan Khmelnytsky himself. The image of Nalyvaiko as a national hero came alive on the pages of the mysterious history, complete with a thorough account of his exploits and texts of his letters to the Polish king. Few images of fighters indeed, martyrs - for the freedom of Rus' were as appealing to the early nineteenth-century mind as that of Nalyvaiko. Ryleev would turn Nalyvaiko into a symbol of Cossack freedom, courage, and patriotism. ${ }^{18}$

Severyn (Semerii) Nalyvaiko, who became a hero of the eighteenthcentury Cossack chroniclers and made a spectacular career with the nineteenth-century Romantics, was a highly controversial figure in his own time. In 1593, as an officer in a Cossack troop employed by the Ukrainian prince Kostiantyn Ostrozky, Nalyvaiko helped defeat the revolt of another Cossack leader, Kryshtof Kosynsky. In the following year, by agreement with Ostrozky, Nalyvaiko took command of Cossack and peasant rebels, seeking to lead them away from his patron's estates and direct their rage and destructive power against his enemies. At the top of that list were two Orthodox bishops who negotiated a church union between the Orthodox metropolitanate on the territory of the Polish-Lithuanian Commonwealth and the pope of Rome at the time of the revolt. The Union of Brest became a reality in 1596, provoking strong opposition to what was regarded as a violation of the rights of the Orthodox Church and the entire nation of Rus', and turning Nalyvaiko, who was captured and executed by the Poles in 1597 , into the first martyr for the cause. ${ }^{19}$

I8 Dmitrii Bantysh-Kamenskii, Istoriia Maloi Rossii (Moscow, I822), vol. I, p. xxii.

19 See Serhii Lep'iavko, Kozats'ki viiny kintsia XVI stolittia v Ukräni (Chernihiv, 1996), pp. I70-72; Serhii Plokhy, The Cossacks and Religion in Early Modern Ukraine (Oxford and New York, 200I), pp. 33-36, 104-7. 
It is hardly surprising that the Orthodox monks and Cossack authors who wrote the Rus' chronicles were most sympathetic to Nalyvaiko and his plight, but the historical data available to them was limited at best. The Konysky History, on the other hand, had plenty of material to play with. Ryleev borrowed details from the manuscript that he could find nowhere else, including references to Nalyvaiko's capital of Chyhyryn on the Tiasmyn River and the treatment of Colonel Hryhorii Loboda as Nalyvaiko's confidant. Those details were not entirely correct. Loboda, who was Nalyvaiko's rival, was executed by the Cossacks on suspicion of collaboration with the Poles. Chyhyryn, which is indeed located on the Tiasmyn River, did not become the Cossack capital until more than half a century after Nalyvaiko's death. But it is not so much the details of Ryleev's narrative, whatever their historical accuracy, as the ideological message embodied in Nalyvaiko as a historical and literary character that betrays Ryleev's reliance on the Konysky History in his treatment of the Cossack leader.

It was under the influence of the Konysky History that Ryleev portrayed Nalyvaiko not only as a man prepared to die defending the freedom of his nation but also as a promoter of equality and friendship among neighboring peoples:
Cossacks were then the Pole's allies
Bound each to each in equal ties,
Such as free men would well beseem -
Now all is vanished like a dream.
Cossacks long since had learned to know
How into tyrants friends may grow. ${ }^{20}$

The notion of an alliance of equals between Cossacks and Poles comes directly from the text of Nalyvaiko's letter to the king as it appears in the Konysky History. In his appeal, Nalyvaiko claims that the nation of Rus' was never conquered by the Kingdom of Poland or the Grand Duchy of Lithuania but "united voluntarily on rights and privileges equal and identical to theirs." Nalyvaiko goes on to argue that those rights had been violated in numerous ways, including the introduction of the church union. It was only after the defeat and execution of Nalyvaiko, according to the text of the Konysky History, that the Poles began to refer to the Orthodox as "schismatics" and lease Orthodox churches to Jews, who

\footnotetext{
${ }^{20}$ Relaieff, Voinarofskyi and Other Poems, p. 132.
} 
were only too happy to turn that situation to their profit and charge the Orthodox exorbitant fees for the use of their own churches. ${ }^{2 \mathrm{I}}$

The claim that Jews held the keys to Orthodox churches later became a rallying cry of those in the Russian Empire who stirred up anti-Semitic sentiments among its subjects. In his poetic play Bogdan Khmelnitsky, Ryleev used this theme to stress the oppression of the Cossacks by the Polish authorities prior to the uprising of 1648 , which claimed tens of thousands of Ukrainian Jews as victims. In so doing, he revealed his acquaintance with another episode of the Konysky History - a description of the defeat of the Polish army at the hands of the Cossacks in the so-called "Night of Taras." This episode of the I620s, like the Nalyvaiko revolt, was known to chroniclers only in general terms, but the Konysky History elaborated it in astonishing detail. Ryleev shared the distaste for Polish rule over Ukrainian lands manifested in the History. He regarded Nalyvaiko and Khmelnytsky as patriots who could not tolerate the oppression of their people by a tyrannical foreign power. For him the Cossacks, to whom he referred interchangeably as "Little Russians" and "Ukrainians," represented a freedom-loving but oppressed part of the Rus' nation. ${ }^{22}$

Few people were as grateful to Ryleev for his heroic portrayal of the Cossack past as the descendants of Cossack officer families in Ukraine. Mykola Markevych, who characterized himself in a letter to Ryleev as "a true citizen of my fatherland and a good Little Russian," wrote with regard to Voinarovsky and Nalyvaiko: "Accept my thanks and those of all compatriots known to me. Rest assured that our thanks are sincere; that we feel in our hearts the value of your works, which glorify you and our ancestors. The deeds of the great men of Little Russia are not yet lost to our sight; in many hearts the former strength of feeling and dedication to our homeland remains undiminished. You will find the spirit of [Hetman Pavlo] Polubotok still living among us. Accept our general thanks: you have done much, a great deal! You uplift the whole nation. Woe to him who seeks to oppress entire countries; who attempts to cover whole nations with contempt, and they repay him with contempt ... But glory to him who praises the greatness of the human soul, and whom whole nations should repay with gratitude. The Confession of Nalyvaiko is engraved in our hearts, and in mine as well." ${ }^{23}$

${ }^{21}$ Istoriia Rusov ili Maloi Rossii. Sochinenie Georgiia Koniskago, Arkhiepiskopa Beloruskago (Moscow, I846), pp. 35-4I.

${ }^{22}$ K. F. Ryleev, "Bogdan Khmel'nitskii," in Sochineniia i perepiska, pp. I45-52; Istoriia Rusov, pp. 5I-52; Zenon Kohut, "The Khmelnytsky Uprising, the Image of Jews, and the Shaping of Ukrainian Historical Memory," Jewish History I7 (2003): I4I-63.

${ }^{23}$ Quoted in Kotliarevskii, Ryleev, pp. II7-I8. 
Kondratii Ryleev drew inspiration for his freedom-loving poetry not only from the Cossack history. He was fascinated with the democratic tradition of the medieval republic of Novgorod and inspired by the Greek revolt of his own day against Ottoman rule. His thinking was nurtured by his reading of contemporary French, Polish, and Russian authors, and his ideas were shaped in discussions with people like the Bestuzhevs, Kornilovich, and Pushkin. Still, the Cossack past provided inspiration for his longest poetical works. He turned to the history of the Cossack revolts of the sixteenth and seventeenth centuries against Polish overlordship in order to make a case for revolt against the Russian autocracy. The young poet viewed the struggle against that government as a patriotic duty, and was prepared to follow the example of the Cossack heroes and die in battle for the freedom of his beloved fatherland. Images drawn from the Konysky History not only helped him articulate his dream of freedom but also foreshadowed his own fate.

Ryleev's last letter, written immediately before he was taken away by the executioners, was addressed to his wife. Like his most famous character, Severyn Nalyvaiko, Ryleev met his own death without regret and "blessed the stroke which laid him low." He wrote to his "good Ukrainian lady": "God and the Sovereign have decided my fate: I am to die, and die a shameful death. May His holy will be done! My dear mate, submit to the will of the Almighty as well, and He will comfort you. Pray to God for my soul. He will hear your prayers. Do not repine against Him or against the Sovereign: that would be both foolhardy and sinful. Is it for us to comprehend the inscrutable judgments of the One who passes understanding? I did not repine even once throughout the time of my imprisonment, and for that the Holy Spirit comforted me in wondrous fashion." He ended his letter with the following words: "Farewell! They are telling me to dress. May His holy will be done." ${ }^{24}$

\footnotetext{
${ }^{24}$ K. F. Ryleev, "Perepiska s zhenoiu iz kreposti," in Sochineniia i perepiska, pp. 300-I.
} 